\title{
Influence of Supplier Integration on Organizational Performance in Food and Beverage Manufacturing Companies in Kenya
}

\author{
Bartoo Dorothy Chebichii *, Professor Gregory Simiyu Namusonge ${ }^{* *}$, Dr Elizabeth Nambuswa Makokha ${ }^{* * *}$ \\ * Phd student in Supply Chain Management, Jomo Kenyatta university of Agriculture and technology, Kenya \\ ** School of Business,Jomo Kenyatta university of Agriculture and Technology,Kenya \\ **** Dr Elizabeth Nambuswa Makokha, School of Business, Jomo Kenyatta University of Agriculture and Technology ,Kenya
}

DOI: 10.29322/IJSRP.11.11.2021.p11949

http://dx.doi.org/10.29322/IJSRP.11.11.2021.p11949

\begin{abstract}
The purpose of the study was to determine the influence of supplier integration on organizational performance in food and beverage manufacturing companies in Kenya. The study employed mixed methods research design. The study used Network theory. The target population was 534 respondents comprising of 217 procurement managers and 217 procurement officers from 217 food and beverage manufacturing companies in Kenya. A sample size of 230 respondents comprising of 115 managers and 115 procurement officers were selected from 115 food and beverage manufacturing companies in Kenya. Simple random sampling was used to get the sample for the study. Purposive sampling was used to get top procurement personnel from the food and beverage manufacturing companies in Kenya. Primary data was collected by the use of a questionnaire. Analysis of data was done using descriptive and regression analysis. From the model, $\left(\mathrm{R}^{2}=.348\right)$ shows that supplier integration accounts for $34.8 \%$ variation in organizational performance in food and beverage manufacturing companies in Kenya. There was a significant influence of supplier integration on performance of food and beverage manufacturing companies in Kenya. The study concluded that supplier integration influences the performance of food and beverage manufacturing companies in Kenya. The study recommends that the managements of food and beverage manufacturing companies add greater comprehensiveness of the supply chain integration by allowing the suppliers to have access to their inventory management systems that will allow them make timely decisions like inventory replenishment. The use of ICT with suppliers should be enhanced by promoting E-procurement that allows order tracking and audit trailing as well as invoice settlement. Supplier integration should be enhanced across all stakeholders of the firm so as to share management techniques, enhance supplier knowledge management and enable the supplier to inform the company of issues affecting order fulfilment. This aids in risk control.
\end{abstract}

Index Terms- Supplier integration, organizational, performance, food and beverage, manufacturing companies.

\section{INTRODUCTION}

$\mathrm{O}$ rganizational performance refers to how well a firm achieves its market-oriented goals and objectives as well as its financial goals. It is a powerful tool for prioritizing firms' goals and attaining them (Kirkendall, 2010). It usually informs the policy makers, implementers as to the position of the firm and some of the challenges that require attention. It also allows for a progressive monitoring of the efficiency and effectiveness of the firms' operations.

The manufacturing sector is lost immensely due to lack of benefit from the research and development initiatives conducted by the suppliers concerning the supplies (Muhia \& Afande, 2015). Effective supplier relationship management requires an enterprise-wide analysis of what activities to engage in with each supplier. The common practice of implementing a "one size fits all" approach to managing suppliers can stretch resources and limit the potential value that can be derived from strategic supplier relationships.

Supply chain integration continues to be a key theme amongst those seeking to understand how to harness the potential of the supply chain to create sustainable value. Kannan \& Tan (2010) view supply chain integration as the strategic integration of both intra- and inter-organizational processes and gauges the extent to which supply chain partners work collaboratively together to gain reciprocally beneficial outcomes. Supply chain integration means the co-operation between various functions in the supply chain. According to Gebreeyesus \& Sonob (2012), Georgise et al., (2014), the performance of an organization is influenced to a greater or lesser degree by the actions of the organization that integrate the inputs and the supply chain to large extents.

Moreover, Huo (2012) shows that supply chain integration can be viewed as internal and external integrative capabilities that lead directly or indirectly to company performance. Even though most of the previous studies address the relationship between supply chain integration and performance, none of the researches conducted show which components of supply chain integration highly impact on performance .In that regard, better supplier relations enhance supply chain performance and adds to competitiveness of suppliers in the market.

Zhao, Feng \& Wang (2015) took a sample of 195 companies in China and realized that supply chain integration is a major facilitator of financial performance, highlighting the role of management taking advantage of the strategic relationships of SCI to boost financial figures. Huo, Qi, Wang \& Zhao (2014) found 
out those companies that have strong internal integration within the business processes create sufficient requirements for the organization to improve their financial performance.

Ralston, Blackhurst, Cantor, \& Crum, (2015) also found out that internal integration improves the company's performance by reducing costs and limiting the ability of departments within the organization from taking steps that would distort the overall goals of the organization In Indonesia, Yunus (2018) sought to establish the effect of supply chain integration and organizational performance. The study showed a positive relationship between supply chain integration and organizational performance.

Locally, Mbaisi (2016) studied the effect of supply chain integration on large manufacturing firms in Kenya. The study established cross-functional integration to be significant to the supply chain performance. Nyamoko (2013) studied the effect of supply chain integration on performance of manufacturing firms. It was established that the manufacturing firms through supply chain integration enable exchange of information regarding demands of the products with key partners and operational coordination which entailed order execution and product designing with key partners.

Cheruiyot (2013) studied the impact of supply chain integration on supply chain performance of KTDA managed tea factories in Kenya. The study established the effect of internal, external and customer integration on the performance of the supply chain. Mbaisi (2016) studied the effect of supply chain integration on large manufacturing firms in Kenya. The study established that the existence of strategic partnership between large manufacturing and their supplier is higher and that they consult their supplier through the electronic platform on the vale of the firm when they are being developed.

The food and beverage manufacturing companies in Kenya depend on suppliers for the raw materials that they put into their production operations. It is imperative to note that financial performance is not the only parameter of success that companies think of since there are other non-financial measures which are currently of sound importance. According to Awino (2011) manufacturing is an important sector in Kenya and it makes a substantial contribution to the country's economic development. It has the potential to generate foreign exchange earnings through exports and diversifies the country's economy. This sector has grown over time both in terms of its contribution to the country's gross domestic product and employment (Nyaoga \& Magutu 2016).

\section{Statement of the problem}

Nyamoko (2013) studied the effect of supply chain integration on performance of manufacturing firms. It was established that the manufacturing firms through supply chain integration enables exchange of information regarding demands of the products with key partners and operational co-ordination which entailed order execution and product designing with key partners. The study concluded that supply chain integration had an effect on the performance of manufacturing firms in Kenya. Cheruiyot (2013) studied the impact of supply chain integration on supply chain performance. In a survey of 165 KTDA managed tea factories in Kenya, the study established the effect of internal, external and customer integration on the performance of the supply chain. With a response rate of $73 \%$, it was found that supply chain integration encompassing customer, internal and supplier integration positively affected supply chain performance under marked by raw material purchasing costs, transport costs, distribution costs, asset turnover and inventory handling costs. The study however, focused on internal, external and customer integration in totality, therefore failing to show the individual contribution of these facets on the performance of the manufacturing firms.

Despite the fact that manufacturing companies in developing economies have acknowledged the significant role supplier integration plays in promoting organizational performance and contributing strategically to overall operational effectiveness, few researchers in these economies have examined the impact of supplier integration on organizational performance in the food and beverage manufacturing companies in Kenya. This study intends to fill this knowledge gap by establishing the influence of supplier integration on performance in the manufacturing sector of Kenya

\section{THEORETICAL FRAMEWORK}

This study adopted the network theory. The rational selfinterest school within network research can be traced back to the work of sociologist Coleman (1988). Coleman showed how, from two-actor interactions, with each actor operating out of selfinterest, emerges the basis for a social system (such as a small group). While each actor is trying to maximize his or her individual interests, each is at the same time constrained because he or she is embedded in an interdependent relationship with the other. The relationship imposes a limit on both actors' behavior and regulates the extent of self-seeking (Nancy, David, Holly \& Noshir, 2013). These limits are counterbalanced by the increased access to resources each actor gets via the other.

The network theory (NT) contributes profoundly in understanding the dynamics of inter- organizational relations such as supply chain relationships by emphasizing the importance of "personal chemistry" between the parties, the build-up of trust through positive long-term cooperative relations and the mutual adaptation of routines and systems through exchange processes. Through direct communication, the relationships convey a sense of uniqueness, ultimately resulting in supply chains as customizations to meet individual customer requirements that enhance supply chain performance.

A network does not seek an optimal equilibrium, but is in a constant state of movement and change. Links between companies in a network develop through two separates, but closely linked, types of interaction: exchange processes (information, goods and services, and social processes) and adaptation processes (personal, technical, legal, logistics, and administrative elements) (Johanson \& Mattsson, 1987). NT is descriptive in nature and has primarily been applied in SCM to map activities, actors, and resources in a supply chain. The focus has been on developing long-term, trustbased relationships between the supply chain members (Gadde \& Haakansson, 2013).

In the current competitive business environment, a single enterprise acting alone cannot fully achieve all management goals. As customer demands increase and become more specific, companies must undertake initiatives to coordinate responsibilities across the supply chain in order to improve service and lower costs. Network theory is built on the same premise that 
companies rely not only on their relationship with direct partners but with the extended network of relationships with supply chain companies, that competitive advantage can only be achieved through efficiently and effectively coordinated supply chains (Ullah, 2012). Network relations create information sharing that enables buyers and sellers to have access to resources and knowledge beyond their abilities hence the need for long-term, trust-based relationship between supply chain companies.

According to Gichuru, Iravo, and Iravo (2015) the performance of a firm depends not only on how efficiently it cooperates with its direct partners, but also on how well these partners cooperate with their own business partners. The firm's continuous interaction with other players becomes an important factor in the development of new resources and in situation where the resources of two organizations are combined, they tend to achieve more advantages than through individual efforts (Haakansson \& Ford, 2002).

Network theory focuses on how elements of the entire supply chain relate (McNichols \& Brennan, 2006). This theory was first introduced during the 1970s and the 1980s and developed from the focus on relationships between business entities, or strategic alliances, towards an approach which entails the entire supply chain (Wellenbrock, 2013). Harland (1996) looks at a network as a specific type of relationship linking a defined set of persons, objects or events.

When the buyer supplier establishes and transact business over a period of time based on capability and resources, they establish bidirectional business relationship and with time a buyer creates a network of reliable suppliers for business transaction (Hakansson \& Ford, 2002). Chang, Chiang \& Pai (2012) argue that the entire supply chain network model is complicated and its specific context depends on the relationships among the network members. Further, networks are seen as beneficial for individual members through investments in the supply chain (Hakansson \& Ford, 2002). The network theory has been utilized in specific manufacturing industries across the world (Peck 2005; Zhao, Anand \& Mitchell, 2005)..

\section{CONCEPTUAL FRAMEWORK}

The objective of the study is to establish the influence of supplier integration on organizational performance of the food and beverage manufacturing companies in Kenya. The conceptual framework for this study was based on the independent variable: supplier integration which influences the dependent variableorganization performance and Figure 1 shows this relationship. Supplier integration was measured using supplier knowledge management, joint inventory management system, knowledge transfer, joint strategic sourcing, supply chain visibility and joint process engineering. The dependent variable organizational performance was established using financial wellbeing, quality of products, improved responsiveness and customer satisfaction.

\section{Independent Variable} variable
Dependent

\begin{tabular}{|c|c|}
\hline $\begin{array}{l}\text { Supplier Integration } \\
\text { - Supplier knowledge } \\
\text { management } \\
\text { - Joint inventory management } \\
\text { - System } \\
\text { - Jnowledge transfer } \\
\text { - Soint strategic sourcing } \\
\text { - Joint process engineering }\end{array}$ & $\begin{array}{l}\text { Organizational } \\
\text { performance } \\
\text { - Profitability } \\
\text { - Quality products } \\
\text { - Improved } \\
\text { - } \text { responsiveness } \\
\text { - Customer satisfaction }\end{array}$ \\
\hline
\end{tabular}

Figure 1. Conceptual Frame work 


\section{LITERATURE REVIEW}

\section{Concept of Organizational Performance}

Corina, Liviu and Roxana (2011) defined performance as a set of financial and non-financial indicators which offer information on the degree of achievement of objectives and results. Overall organizational performance can be divided into three parts: financial performance, product performance, and operational performance (Inayatullah, 2012). Organizational performance refers to how well an organization achieves its objectives. Common organizational objectives include shareholder wealth maximization, profit maximization, increased market share and customer satisfaction (Brigham \& Houston, 2014).

According to Phanet et al., (2011), cost performance is measured in terms of the unit cost of manufacturing while quality performance is measured using product capability and performance. On the other hand, flexibility performance is determined by organizational flexibility while delivery performance is measured in relation to degree of timely delivery. Subsequently, the relationship paradigm is a composition of all the activities that are channeled towards the establishment, development and maintaining of successful relational exchange claims Stevens (2011). Value in organizations is not created in isolation but through the nurturing of key competencies which spurn to the supplier relationship management. There is a belief among organizations that strategic supplier management provides the vital benefits when creativity is natured among suppliers which in turn will translate to value benefits to an organization (Taraf dar \& Qrunfleh, 2013). In the manufacturing sector, the measure of performance is in the form of different metrics such as schedule performance.

Abdifatah (2012) argued that performance is not uniform in all organization and keen considerations is needed on different factors such as effectiveness and efficiency of internal operations, flexible production processes, good supplier relationship management, customer relationship management and continuous improvement in the firms' operations. The dependent variable organizational performance was established using financial wellbeing, quality of products, improved responsiveness and customer satisfaction

\section{Concept of Supplier Integration}

Effective supply chain management and supply chain (SC) integration are becoming increasingly critical factors for business success (Georgise et al., 2014). Supply chain integration can be defined as the degree to which a firm can strategically work together with its supply chain partners and cooperatively manage intra- and inter-organizational processes to achieve effective and efficient flows of products, services, information, money, and decisions to provide the maximum value to the final customer with low costs and high speed Huo (2012). Supply chain member organizations integrate into three dimensions customer, supplier and internal integration. These dimensions are considered as independent variables of supply chain integration in manufacturing industries (Flynn et al., 2010). The success of coordination, integration management of key business across the members of the supply chain will determine the ultimate success of the single industry.
An enormous deal of research has been done on the importance of integrating suppliers, manufacturers, distributors, retailers, and customers Huo (2012), Rehme, (2012), Hatani et al (2013) \& Rakhman et al., (2016). Negussie (2014) shows in a supply chain evaluation study that developing nation's leather industries are suffering from the shortage and quality issues in its raw material (hides and skins), possibly, if suppliers were integrated into the buyers' business, these problems would have been eliminated altogether or minimized.

Numerous studies have been conducted to show that supply chain integration leads to improved financial performance and profitability. In their study Zhao, Feng \& Wang (2015) took a sample of 195 companies in China and realized that supply chain integration is a major facilitator of financial performance, highlighting the role of management taking advantage of the strategic relationships of SCI to boost financial figures. Huo, Qi, Wang \& Zhao (2014) found out those companies that have strong internal integration within the business processes creates sufficient requirements for the organization to improve their financial performance.

When members of a supply chain are integrated and there is proper communication flow, they are able to quickly adjust to any changes in the market place whether in the long run or short run Seebacher \& Winkler (2015), thus improving their flexibility. SCI has been found to be a facilitator of shortening the lead times between processes and improved product availability. SCI with partnerships involves a win-win situation helping organizations to look for the best possible ways to reduce costs across the supply chain whether it is manufacturing, inventory or transaction costs and boosts profitability of every member in the supply chain (Deshpande, 2012). Thus, it is evident that SCI brings numerous benefits to organizations.

In their study, Ralston, Blackhurst, Cantor, \& Crum, (2015) also found out that internal integration improves the company's performance by reducing costs and limiting the ability of departments within the organization from taking steps that would distort the overall goals of the organization. The studies from the global perspective showed a positive relationship between supply chain integration and firms' performance, however, the studies were done from different countries and a different type of industry of operation. Choi, Narasimhan \& Kim (2016) on his study on supply chain integration and performance of Korean and Japanese firms , showed a positive relationship linking supply chain integration and firms' performance.

In a census survey of the incorporation in Indonesia, Yunus (2018) sought to establish the effect of supply chain integration on organizational performance. He established that a large extent of supply chain integration in the firms in Indonesia, which was characterized with ERP tools and functional coordination that lead to increase in the customer satisfaction through demand planning, reduction in lead-time, timely delivery and prompt decisionmaking is evident. The study used a descriptive analysis and the use of questionnaires to carry the research, which the study showed a positive relationship between supply chain integration and organizational performance. However, the study focused on firms in Indonesia, whose mode of operation could be different from those in Kenya.

Njagi and Shalle (2016) did a study on the Role of Supplier Relationship Management on Procurement Performance in the 
Manufacturing Sector in Kenya. The study used the case of East African Breweries Ltd and focused on employees working in different departments at the Company. The results indicated that supplier integration contributed significantly to the procurement performance. This study did not look at the overall performance of the organization.

Locally, Mbaisi (2016) studied the effect of supply chain integration on large manufacturing firms in Kenya. The study established cross-functional integration to be significant to the supply chain performance. The study however, focused on manufacturing plant and single aspect of supply chain integration. Nyamoko (2013) studied the effect of supply chain integration on performance of manufacturing firms. It was established that the manufacturing firms through supply chain integration enables exchange of information regarding demands of the products with key partners and operational co-ordination which entailed order execution and product designing with key partners. It was concluded that information sharing and operation coordination has an effect on the performance of the firm. Performance was measured by ROI, Market Share, and sales growth. The study concluded that supply chain integration had an effect on the performance of manufacturing firms in Kenya.

Cheruiyot (2013) studied the impact of supply chain integration on supply chain performance. In a survey of 165 KTDA managed tea factories in Kenya, the study established the effect of internal, external and customer integration on the performance of the supply chain. With a response rate of $73 \%$, it was found that supply chain integration encompassing customer, internal and supplier integration positively affected supply chain performance seen through raw material purchasing costs, transport costs, distribution costs, asset turnover and inventory handling costs. The study however, focused on all the three facets of supply chain integration.

Mbaisi (2016) studied the effect of supply chain integration on large manufacturing firms in Kenya. The study employed descriptive research design in carrying out the research study. A survey method was conducted with the use of the structured questionnaire to measure the extent of supply chain integration on the large manufacturing firms in Kenya. The study established that the existence of strategic partnership between large manufacturing firms and their suppliers is high as they consult their supplier through the electronic platform. However, this study focused on overall large manufacturing firms, but the current study narrowed down to the specific food and beverage manufacturing companies in Kenya.

\section{RESEARCH MethodOlOGY}

The researcher used descriptive survey research design. Descriptive survey design enabled the researcher to summarize and organize data in an effective way (Kireru, 2014). It provided tools for describing collections of statistical observations and reducing information to an understandable form. A descriptive research design was suitable where the study sought to describe and portray characteristics of an event, situation and a group of people, community or population which is the case adopted in this study.

The target population of this study was all the 217 food and beverage manufacturing companies drawn from all over the major towns and cities in Kenya. The target population was 534 respondents comprising of 217 procurement managers and 217 procurement officers from 217 food and beverage manufacturing companies.

The sampling frame for this study was all of the 217 foods and beverage manufacturing companies in Kenya as listed by the Kenya Association of Manufacturers. The researcher used purposive and simple random sampling technique to select the sample size. Procurement officers and managers was purposively selected from the foods and beverage manufacturing companies in Kenya. One procurement officer and one procurement manager per company was purposively selected to take part in this research. After purposively selecting the procurement officers and managers, simple random sampling was used as a major sampling technique because each respondent had an equal chance of inclusion in the sample. Simple random sampling was appropriate because the entire population is relatively large, diverse and sparsely distributed.

The researcher sampled all the 115 foods and beverage manufacturing companies in Kenya. Using Yamane's (1972) sample size formula at $95 \%$ confidence level, $\mathrm{P}=0.05$, the sample size was computed as hereunder:

$$
\text { n }=\frac{\mathrm{N}}{1+\mathrm{N}(e)^{2}}
$$

Where; $\mathbf{n}=$ the $\quad$ sample size, $\mathbf{N}=$ the population size, $\mathrm{e}=$ the acceptance sampling error

$=534 / 1+534(.05)^{2}$

$=230$ respondents

From the target population of 534 respondents a sample of 115 managers and 115 procurement officers was selected from 115 food and beverage manufacturing companies.

A questionnaire was the most appropriate tool for collecting primary data from the respondents. The questionnaire was appropriate as it allows data to be collected in a quick and efficient manner. A five-point Likert scale was used for every question or statement that represent the degree of agreement to the given question. The researcher constructed closed-ended questionnaires, which was administered to 115 procurement officers and 115 managers from each of the selected companies under study.

Before embarking on the actual research, the researcher undertook a preliminary study to ascertain the validity and reliability of the research instruments. To test the validity and reliability of the questionnaire used for this study, the researcher pilot-tested the questionnaire. Piloting of the instruments was done using 12 managers and 12 procurement officers from food and beverage manufacturing companies in Kenya who were not included in the final study. The pilot study was conducted to refine the questionnaire, identify loopholes in the questionnaire and anticipate any logistical problems during the actual survey.

Validity is the extent to which a construct measures what it is supposed to measure (Saunders et al, 2007). During questionnaire development, various validity checks were conducted to ensure the instrument measures what it is supposed to measure. There are three important approaches to assessing measurement validity: content validity (also referred to as face validity), construct validity and criterion validity. The current study utilized content and construct validities. 
To ensure content validity, discussions was held with experts during the questionnaire formulation stage to ensure that the measure includes an adequate and representative set of items that tap the content and ensure the questions conform to the study objectives. Content validity of the instrument was determined by the researcher using expert judgment. This was done by discussing the items in the instrument with the supervisors, lecturers from the department and colleagues. Construct validity assesses what the construct or scale is in fact measuring. Construct validity was maintained through anchoring of the constructs to the theory from which they are derived.

Reliability of an instrument is the measure of the degree to which a research instrument yields consistent results or data after repeated trials. Reliability was measured using Cronbach's alpha method. The Cronbach's alpha coefficient was an appropriate measure of variance attributable to subjects and variance attributable to the interaction between subjects and items. A reliability coefficient of 0.7 and above was assumed to reflect the internal reliability of the instruments (Fraenkel \& Wallen, 2000). After all data had been collected, the researcher conducted data cleaning, which involved identification of incomplete or inaccurate responses and corrected to improve the quality of the responses. The data was coded and entered in the computer for analysis using the Statistical Package for Social Sciences (SPSS V23). The research yielded quantitative data. Quantitative techniques such as descriptive statistics and inferential statistics were used to understand relationships between different variables. The main descriptive statistical analysis that was used include mean, percentages, standard deviation and frequencies to cater for the Likert scales that have been used in the study. Inferential statistics was used to analyze relationship between variables using linear regression analysis. Linear regression is a parametric statistic used since the data adheres to the following assumptions (Field, 2009); data must be on interval level, a linear relationship exists, the distributions is normal, outliers were identified and omitted. Data was presented by use of tables and graphs.

The Linear regression model assumed the following form:

$\mathrm{Y}=\beta_{\mathrm{o}}+\beta_{1} \mathrm{X}_{1}+\varepsilon \ldots \ldots \ldots \ldots \ldots \ldots \ldots \ldots \ldots \ldots \ldots \ldots \ldots$. Equation 3.1

$\mathrm{Y}$ is Organizational performance.

$\beta_{\mathrm{o}}, \beta_{1}$-coefficients of organizational performance.

$\mathrm{X}_{1}-$ Supplier integration

$\varepsilon-$ Error Term

\section{RESULTS}

\section{Performance in food and beverage manufacturing companies in Kenya.}

The dependent variable was organizational performance in food and beverage manufacturing companies in Kenya. The study sought to find out from respondents their view on performance in food and beverage manufacturing companies. The respondents were asked to indicate their agreement on various aspects of performance in food and beverage manufacturing companies using a 5-likert scale. A total of 10 items were used to explore the respondent's views on performance in food and beverage manufacturing companies and findings are presented in Table 1. Majority of the respondents $185(88.9 \%$ ) agreed that both the company and its suppliers have the same goals, with $1.9 \%$ undecided and 9.2\% disagreed $(M=4.15 ; S D=0.99)$. Most of the respondents $200(96.2 \%$ ) agreed that it was easy to solve a business problem between suppliers and the company because of the collaboration they have, with $1 \%$ disagreeing and $2.9 \%$ undecided $(M=4.33$; $S D=0.58)$. Majority of the respondents $194(93.3 \%)$ agreed that both the company and its suppliers are financially sound due to their close relationship, with $5.8 \%$ undecided and $1 \%$ disagreed $(M=4.32 ; S D=0.67)$.

Table 1: Performance in food and beverage manufacturing companies in Kenya

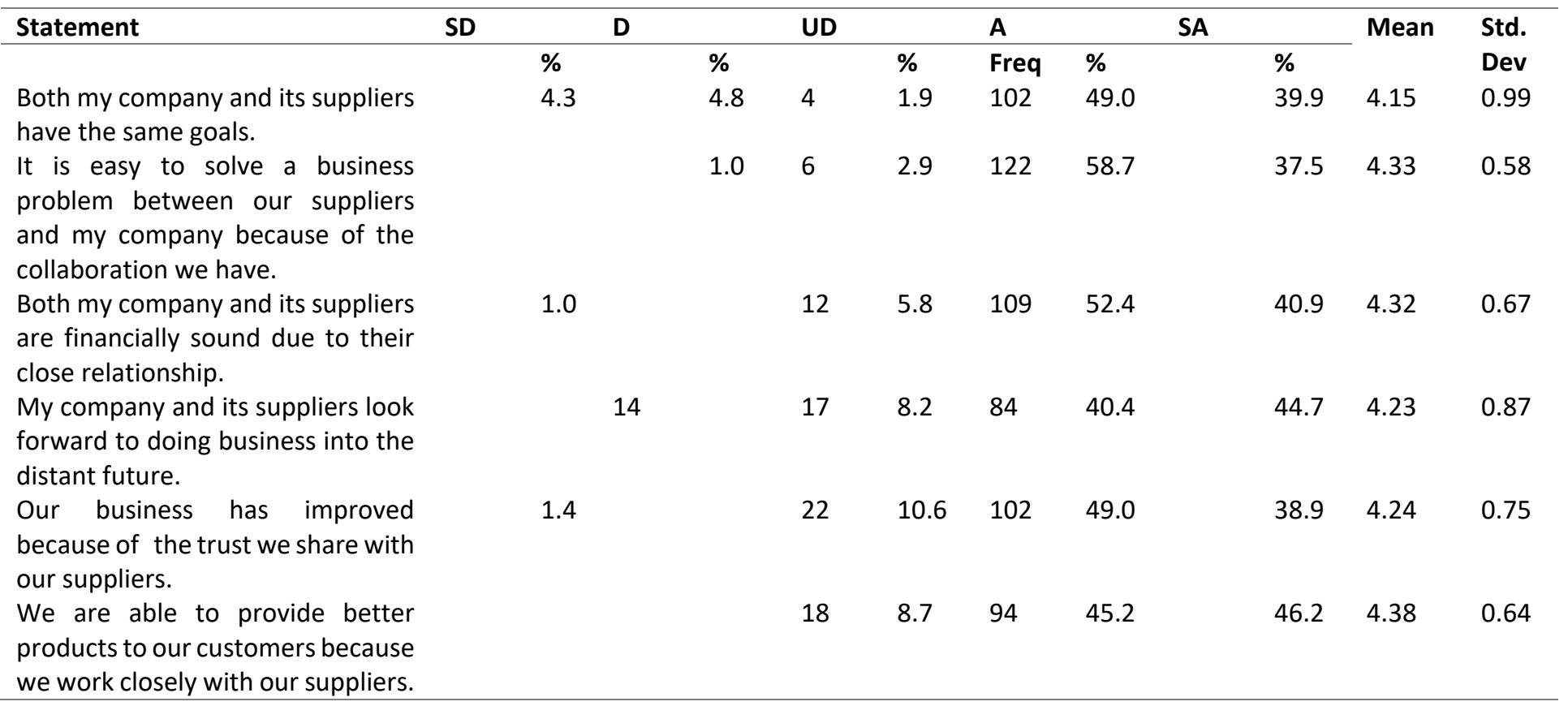


My company has been able to

deliver services to its customers at

a reduced cost due to supply chain

integration

We serve our customers fast because we work closely with our suppliers.

The integration of technology, people, business and processes has enhanced the company's competitive edge in the current digital age

We have been able to deal with abrupt changes in our business environment because we share information with our suppliers.

\begin{tabular}{|c|c|c|c|c|c|c|c|c|c|}
\hline 1.0 & 3 & 1.4 & 10 & 4.8 & 74 & 35.6 & 57.2 & 4.47 & 0.74 \\
\hline 1.0 & & & 15 & 7.2 & 97 & 46.6 & 45.2 & 4.35 & 0.70 \\
\hline & 35 & 16.8 & 26 & 12.5 & 79 & 38.0 & 32.7 & 3.87 & 1.05 \\
\hline & & & 17 & 8.2 & 94 & 45.2 & 46.6 & 4.38 & 0.63 \\
\hline
\end{tabular}

Most of the respondents $177(85.1 \%$ ) agreed that their company and its suppliers look forward to doing business into the distant future, with $6.7 \%$ disagreeing and $8.2 \%$ undecided $(M=4.23 ; S D=0.87)$. Majority of the respondents $183(87.9 \%)$ agreed that their business had improved because of the trust they share with our suppliers, with $10.6 \%$ undecided and $1.4 \%$ disagreed $(M=4.24 ; S D=0.75)$. Most of the respondents $190(91.4 \%)$ agreed that they are able to provide better products to their customers because they work closely with the suppliers and $8.7 \%$ were undecided $(M=4.38 ; S D=0.64)$.

Majority of the respondents 193(92.8\%) agreed that the company has been able to deliver services to its customers at a reduced cost due to supply chain integration, with $4.8 \%$ undecided and $2.4 \%$ disagreeing $(M=4.47 ; S D=0.74)$. Most of the respondents $191(91.8 \%)$ agreed that they serve their customers fast because they work closely with them with $1 \%$ disagreeing and $7.2 \%$ undecided $(M=4.35 ; S D=0.70)$. Majority of the respondents $147(70.7 \%)$ agreed that integration of technology, people, business and processes have enhanced the company's competitive edge in the current digital age, with $12.5 \%$ undecided and $16.8 \%$ disagreeing $(M=3.87 ; S D=1.05)$. Most of the respondents $191(91.8 \%)$ agreed that they have been able to deal with abrupt changes in their business environment because they share information with their suppliers. $8.2 \%$ were undecided $(M=4.38$; $S D=0.63)$.
A total of 10 items were used to explore the respondent's views on the performance in food and beverage manufacturing companies in Kenya. The overall mean response score among the respondents on organizational performance in food and beverage manufacturing companies in Kenya was 4.27 and standard deviation of 0.40 . This value lies in the interval which implies that respondents appeared to agree with organizational performance in food and beverage manufacturing companies in Kenya. Moreover, the overall standard deviation was quite small, an indication of the respondents on the performance in food and beverage manufacturing companies in Kenya.

\section{Supplier Integration in Food and Beverage Manufacturing Companies}

A quantitative analysis of questionnaire responses was conducted to identify their views on supplier integration in food and beverage manufacturing companies in Kenya. A total of 10 statements were used to determine the supplier integration using a 5-point likert scale and responses presented in Table 2. Majority of the respondents $171(82.2 \%)$ agreed that the company shares management techniques with other firms in the industry, with $5.3 \%$ undecided and $12.5 \%$ disagreed $(M=4.19 ; S D=1.12)$. Most of the respondents $150(72.1 \%$ ) agreed that the company controls risk associated with supplier's operations, with $18.8 \%$ disagreeing and $9.1 \%$ undecided $(M=3.75 ; S D=1.16)$.

\section{Table 2: Supplier integration in food and beverage manufacturing companies}

\begin{tabular}{|c|c|c|c|c|c|c|c|}
\hline \multirow[t]{2}{*}{ Statement } & SD & D & UD & $\mathbf{A}$ & SA & Mean & Std. \\
\hline & $\%$ & $\%$ & $\%$ & $\%$ & $\%$ & & \\
\hline $\begin{array}{l}\text { My company shares management techniques with other firms in the } \\
\text { industry }\end{array}$ & 3.8 & 8.7 & 5.3 & 28.8 & 53.4 & 4.19 & 1.12 \\
\hline The company controls risk associated with supplier's operations & 5.8 & 13.0 & 9.1 & 44.2 & 27.9 & 3.75 & 1. \\
\hline $\begin{array}{l}\text { Better relationship between our company and its suppliers has } \\
\text { helped to improve the acceptance of our products in the market. }\end{array}$ & 2.4 & & 10.1 & 48.6 & 38.9 & 4.22 & \\
\hline $\begin{array}{l}\text { The ability of the company to manage effectively its supplier's } \\
\text { knowledge has enabled it to manage uncertainty better }\end{array}$ & 1.0 & 8.7 & & 44.2 & 46.2 & 4.35 & \\
\hline $\begin{array}{l}\text { Effective management of the supplier's knowledge by the company } \\
\text { has increased quality of the brand of our products }\end{array}$ & 5.3 & 4.3 & 8.2 & 50.5 & 31.7 & 3.99 & \\
\hline
\end{tabular}


Information sharing by allowing suppliers to access our inventory managed system has increased the reliability of order fulfillment Intra-organizational knowledge transfer has been enhanced by the company's capacity to link its operational system with its suppliers The Company's suppliers keep them fully informed about the issues that affect their businesses in comparison to its competitors

The trust between our company and its suppliers has been developed to such an extent that fear of disclosing information to competition does not exist

Due to the company's strategic sourcing relationship, the company has been able to meet customer demands better

Mean

Majority of the respondents $182(87.5 \%)$ agreed that better relationship between the company and its suppliers has helped to improve the acceptance of its products in the market, with $10.1 \%$ undecided and $2.4 \%$ disagreeing $(M=4.22 ; S D=0.81)$. Most of the respondents $186(90.4 \%)$ agreed that ability of the company to manage effectively its supplier's knowledge has enabled it to manage uncertainty better and $9.7 \%$ disagreed $(M=4.35$; $S D=0.72$ ).

Majority of the respondents 171(82.2\%) agreed that effective management of the supplier's knowledge by the company has increased quality of the brand of the products, with $8.2 \%$ undecided and 9.6\% disagreeing $(M=3.99 ; S D=1.03)$. Most of the respondents $163(78.3 \%)$ agreed that information sharing by allowing suppliers to access the company's inventory management system has increased the reliability of order fulfillment with $14.9 \%$ disagreeing and $6.7 \%$ undecided $(M=3.89$; $S D=1.06)$.

Majority of the respondents $171(82.2 \%)$ agreed that intraorganizational knowledge transfer has been enhanced by the company's capacity to link its operational system with its suppliers, with $13 \%$ undecided and $4.8 \%$ disagreeing $(M=4.24$; $S D=0.89)$. Most of the respondents $178(85.6 \%)$ agreed that the company's suppliers keep them fully informed about the issues

$\begin{array}{lllllll}3.4 & 11.5 & 6.7 & 49.5 & 28.8 & 3.89 & 1.06 \\ 1.0 & 3.8 & 13.0 & 34.6 & 47.6 & 4.24 & 0.89 \\ 4.3 & 8.2 & 1.9 & 42.8 & 42.8 & 4.12 & 1.08 \\ 2.9 & 1.0 & 4.8 & 56.3 & 35.1 & 4.20 & 0.81 \\ & & & & & & \\ 2.4 & 1.4 & 6.3 & 50.5 & 39.4 & 4.23 & 0.83 \\ & & & & & \mathbf{4 . 1 2} & \mathbf{0 . 5 4}\end{array}$

that affect their businesses in comparison to its competitors with $12.5 \%$ disagreeing and $1.9 \%$ undecided $(M=4.12 ; S D=1.08)$. Majority of the respondents $190(91.4 \%)$ agreed that trust between the company and its suppliers has been developed to such an extent that fear of disclosing information to competition does not exist, with $4.8 \%$ undecided and $3.9 \%$ disagreeing $(M=4.20$; $S D=0.81$. Most of the respondents $187(89.9 \%$ ) agreed that with the company's strategic sourcing relationship, the company has been able to meet customer demands better, with 3.8\% disagreeing and $6.3 \%$ undecided $(M=4.23 ; S D=0.83)$.

\section{Influence of supplier integration on organization performance}

A linear regression model was used to explore the relationship between supplier integration and organization performance in food and beverage manufacturing companies in Kenya. From the model, $\left(\mathrm{R}^{2}=.348\right)$ shows that supplier integration accounts for $34.8 \%$ variation in organization performance as shown in Table 3.

Table 3: Model Summary on Supplier integration and organization performance

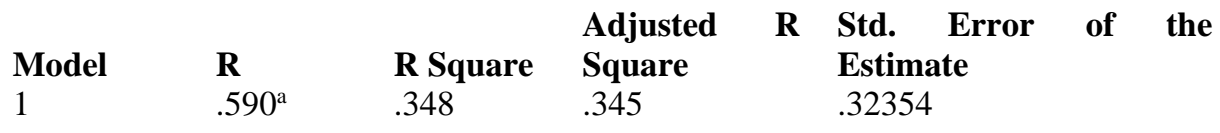

a. Predictors: (Constant), supplier integration

The regression model with supplier integration as a predictor was significant $(\mathrm{F}=110.038, \mathrm{p}=0.000)$ as shown in (Table 4$)$. This shows that there is a significant influence of supplier integration on organization performance in food and beverage manufacturing companies in Kenya. 
Table 4: Analysis of Variance on Supplier integration and organization performance

$\begin{array}{llll}\text { Model } & & \text { Sum of Squares } & \text { df } \\ 1 & \text { Regression } & 11.519 & 1 \\ & \text { Residual } & 21.564 & 206 \\ & \text { Total } & 33.083 & 207\end{array}$

a. Dependent Variable: Performance

b. Predictors: (Constant), supplier integration

Table 5 shows the estimates of $\beta$-value and gives contribution of the predictor to the model. From the findings the t-test associated with $\beta$-values was significant and supplier integration as the predictor made a significant contribution to the model. The $\beta$-value for supplier integration had a positive coefficient,

$\begin{array}{lll}\text { Mean Square } & \text { F } & \text { Sig. } \\ 11.519 & 110.038 & .000^{\mathrm{b}} \\ .105 & & \end{array}$

depicting positive relationship with organization performance as summarized in the model as:

$\mathrm{Y}=2.461+0.440 \mathrm{x}+\varepsilon$

Equation 1

Where: $\mathrm{Y}=$ Organization performance, $\mathrm{X}=$ Supplier integration, $\varepsilon=$ error term

Table 5: Supplier integration and organization performance Coefficients

\begin{tabular}{|c|c|c|c|c|c|c|}
\hline \multirow[t]{2}{*}{ Model } & & \multicolumn{2}{|c|}{$\begin{array}{l}\text { Unstandardized } \\
\text { Coefficients }\end{array}$} & $\begin{array}{l}\text { Standardized } \\
\text { Coefficients }\end{array}$ & $\mathbf{t}$ & Sig. \\
\hline & & B & Std. Error & Beta & & \\
\hline 1 & (Constant) & 2.461 & .174 & & 14.138 & .000 \\
\hline & Integration & .440 & .042 & .590 & 10.490 & .000 \\
\hline
\end{tabular}

\section{a. Dependent Variable: Performance}

The study findings depicted that there was a positive significant influence of supplier integration on organization performance $\left(\beta_{1}=0.440\right.$ and $\left.p<0.05\right)$. Supplier integration had a significant influence on organizational performance of food and beverage manufacturing companies in Kenya. Therefore, an increase in supplier integration led to a rise in performance of food and beverage manufacturing companies. The null hypothesis (Ho1) was rejected. This agrees with Kannan \& Tan (2010) that supply chain integration is the strategic integration of both intraand inter-organizational processes and gauges the extent to which supply chain partners work collaboratively together to gain reciprocally beneficial outcomes.

Huo (2012) shows that supply chain integration is an internal and external integrative capability that lead directly or indirectly to company performance. The supplier integration influences the performance of food and beverage manufacturing companies. This agrees with Choi et al., (2016) that there was a positive relationship linking supply chain integration and firms' performance. It concurs with Ijomba (2010) that the company improved its performance due to an incorporated supply chain, which was evident on higher profitability and increased customer satisfaction.

This finding agrees with Lisanza (2013) that sharing of information within the organization improved functional performance which lead to an improved organizational performance. Nyamoko (2013) found that that the manufacturing firms through supply chain integration enables exchange of information regarding demands of the products with key partners and operational co-ordination which entailed order execution and product designing with key partners. The study concluded that integration had an effect on the performance of manufacturing firms in Kenya.
There was a significant positive influence of supplier integration on performance of food and beverage manufacturing companies $(\mathrm{r}=0.590, \mathrm{p}=0.000)$. Therefore, the more supplier integration led to an increase in performance of food and beverage manufacturing companies. From regression model there was a significant positive relationship between supplier integration and performance of food and beverage manufacturing companies $\left(\beta_{2}=0.173\right.$ and $p$ value $\left.<0.05\right)$. The null hypothesis $\left(\mathbf{H}_{02}\right)$ was rejected. An increase in supplier integration led to a rise in performance of food and beverage manufacturing companies. The supplier integration influences the performance of food and beverage manufacturing companies. The supply chain integration enables exchange of information regarding demands of the products with key partners and operational co-ordination which entailed order execution and product designing with key partners. The study concluded that integration had an effect on the performance of manufacturing firms in Kenya.

\section{CONCLUSIONS}

There was a significant positive influence of supplier integration on performance of food and beverage manufacturing companies in Kenya. The study concluded that supplier integration influences the performance of food and beverage manufacturing companies. The companies share management techniques like policy on order fulfillment, inventory control, total quality management, with their suppliers and therefore control risks ranging from extended lead times, failure to supply or poor quality of products associated with supplier's operations. There was effective management of the supplier's knowledge by the companies which has increased the quality of the brand of their products. Information sharing and allowing suppliers to access inventory management system enabled suppliers inform the buyers on issues affecting order fulfilment and through this, 
supplies were expedited and decision making was based on the data shared by the two parties.

\section{RECOMMENDATIONS}

This study recommends that management of food and beverage manufacturing companies in Kenya should enhance supplier integration through the use of ICT with suppliers adopting E-procurement that allows order tracking and audit trailing as well as invoice settlement since Supplier integration has been shown to enable the firms to share management techniques, enhance supplier knowledge management and enable the supplier inform the company of issues affecting order fulfilment. This aids in risk control.

\section{REFERENCES}

[1] Abdifatah, H., (2012). Supply Chain Management Practices and their Impact on Performance among Humanitarian Organizations in Kenya. Project Research presented to the University of Nairobi, School of Business.

[2] Adhaya, Z. (2013). Supply chain management practices of agricultural sector parastatals In Kenya. Unpublished MBA thesis, University of Nairobi.

[3] Awino, Z. B. (2012). An empirical investigation of selected strategy variables on companies Performance: A study of supply chain management in large private manufacturing companies in Kenya. Journal of Public Administration and Policy Research, 3(8), 228-236.

[4] Brigham, E. \& Houston, J. F. (2014). Fundamentals of financial management (10th ed.). New Delhi: South-Western.

[5] Buchholz, W., \& Appelfeller, W. (2011). Supplier Relationship Management: strategy, organization and IT of modern procurement management. Harsdorf: Springer-Verlag.

[6] Chang, C. W., Chiang, D. M., \& Pai, F. Y. (2012). Cooperative strategy in supply chain networks. Industrial Marketing Management, 41(7), 1114-1124.

[7] Chopra, S., \&Sodhi, M. S. (2014). Reducing the risk of supply chain disruptions. MIT Sloan Management Review, 55(3), 73.

[8] Christopher, M. (2016). Logistics \& supply chain management. Pearson Uk.

[9] Coleman, J. S. (1988). Social capital in the creation of human capital. American journal of sociology, 94, S95-S120.

[10] Corina, G., Liviu, I., and Roxana, S. (2011). Determinants of organizati onal performance: The case of Romania. Management and Marketing Challenges for the Knowledge Society, 6 (2), 285-300.

[11] Duru, A. N., Ekwe, M. C., \&Okpe, I. I. (2014). Accounts receivable management and corporate performance of companies in the food \& beverage industry: evidence from Nigeria. European Journal of Accounting Auditing and Finance Research, 2(10), 34-47.

[12] Fawcett, E., Stephen, L., and Amydee, M., (2012). Supply chain trust: The catalyst for collaborative innovation. Business Horizons, 55(2), 163-178.

[13] Field, A. P. (2009). Discovering statistics using SPSS. London: Sage publications.

[14] Fraenkel, J. R., and Wallen, N. E. (2006). How to design and evaluate research in Education. London, U.K: McGraw Hill.

[15] Frödell, M. (2014). Organisation of purchasing and buyer-supplier relationships in large construction companies. Unpublished $\mathrm{PhD}$ thesis, Chalmers University of Technology.

[16] Gadde, L.E., \& Håkansson, H. (2013). Supply Network Strategies. (2nd ed.) Chippenham: John Wiley \& Sons Ltd.

[17] Gichuru, M., M. Iravo, \& W. Iravo. (2015). "Collaborative Supply Chain Practices on Performance of Food and Beverages Companies: A Case Study of Del Monte Kenya Ltd.”. International Journal of Academic Research in Business and Social Sciences. 5(11):17 - 31.

[18] Grekova, K., Calantone, R. J., Bremmers, H. J., Trienekens, J. H., \& Omta, S. W. F. (2016). How environmental collaboration with suppliers and customers influences firm performance: evidence from Dutch food and beverage processors. Journal of cleaner production, 112, 1861-1871.

[19] Gunasekaran, A., Subramanian, N., \& Rahman, S. (2015). Green supply chain collaboration and incentives: Current trends and future directions.
[20] Haakansson, H. \& D. Ford. (2002). How Companies Interact in Business Networks? Journal of Business Research. 55:133-139.

[21] Harland, C. M. (1996). Supply chain management: relationships, chains and networks. British Journal of management, 7, S63-S80.

[22] Hassan, T. R., Habib, A., \& Khalid, M. (2014). Role of buyer-supplier relationship on buying firm's performance in chemical sector of Pakistan. European Journal of Business and Management, 6(28), 51-57.

[23] Inayatullah, Rakesh Narain, and Amar Singh (2012). Role of buyer-supplier relationship and trust on organizational performance. Delhi Business Review Vol 13,No 2

[24] Johanson, J. and Mattsson, L.G. (1987). Inter- organizational relations in industrial systems: a network approach compared with the transaction cost approach. Inter-Organizational Studies of Management and Organization, 17 (1), 34-48

[25] Kamau, F. (2013), "Buyer-supplier relationships and organizational performance among Large manufacturing firms in Nairobi, Kenya" Unpublished MBA Project, University of Nairobi

[26] Kirkendall, N. (2010). Organizational Performance Measurement In The Energy Information Administration. Energy Administration Department.

[27] Maku, J. K., \& Iravo, M. A. (2013). Effects of outsourcing on organizational performance at Delmonte Kenya Limited. International Journal of Social Sciences and Entrepreneurship, 1(5), 104-117.

[28] Mohanty, M. D., \& Gahan, P. P. (2015). Supply Chain Management-Supplier relationship management and strategic outsourcing. E-Book, Lambert Publication, ISBN: 978-3-659-80551, 6, 103.

[29] Moore, N. (2012). Supplier Relationship Management at Army Life Cycle Management Commands: Gap Analysis of Best Practices. Washington DC: Rand Corporation.

[30] Mugarura, J. (2010). Supplier integration, Adaptation, Trust, Commitment And Relationship Continuity Of Selected Private Manufacturing Firms In Kampala- Uganda. Unpublished Thesis, Makerere University.

[31] Muhia, D. W. and Afande, F. O. (2015). Adoption of e-procurement strategy and procurement performance in State Corporations in Kenya: A Case of Kenya Revenue Authority. Industrial Engineering Letters. 5(6), 1-24.

[32] Muller, R. (2010). Supplier Relationship Management (SRM): basic concepts, strategies, potential. Norderstedt: GRIN Verlag.

[33] Munyambu, F. M. (2015). Employee perception of the influence of human relations on job satisfaction at the ministry of foreign affairs and international trade (Doctoral dissertation, University of Nairobi).

[34] Nancy, K., David, L., Holly, A \& Noshir, C. (2013). Network Theory and Small Groups. Small Group Research, 35 (3), 307-332

[35] Nyaoga, R., \& Magutu, P. (2016). Constraints management and value chain performance for sustainable development. Management Science Letters, 6(6), 427-442.

[36] Oliver, C. (1990). Determinants of inter-organizational relationships: Integration and future directions. Academy of management review, 15(2), 241-265.

[37] Pacheco Lacerda, D., Augusto Cassel, R., \& Henrique Rodrigues, L. (2010) Service process analysis using process engineering and the theory of constraints thinking process. Business Process Management Journal, 16(2), 264-281.

[38] Peck, H. (2005). Drivers of supply chain vulnerability: an integrated framework. International journal of physical distribution \& logistics management.

[39] Petrovic-Lazarevic, S., Sohal, A., \& Baihaqi, I. (2007). Supply chain management practices and supply chain performance in the Australian manufacturing industry. Monash University Faculty of Business and Economics.

[40] Phan, C. A., Abdallah, A. B., \& Matsui, Y. (2011). Quality management practices and competitive performance: Empirical evidence from Japanese manufacturing companies. Int. J. Production Economics, 133(2), 518-529.

[41] Plane, C. V., \& Green. A. N. (2012). Supplier integration: The aim of FM procurement? Facilities, 30, 152-163.

[42] Saunders MP, Lewis A. Thornhill (2007), Research methods for business students. The UK: Pearson Education Limited.

[43] Shalle, N. I., Guyo, W., \& Amuhaya, I. M. (2014). Role of inventory optimization on e-procurement performance in State Parastatals in Kenya. International Journal of Social Sciences and Entrepreneurship, 1(10), 86-96. 
[44] Spekman, R. (2006). Characteristics of partnership success: Communication and conflict resolution. Strategic Management Journal, 11(5), 538-550.

[45] Stevens, M. (2011). Buyer-supplier Relationship Management: Towards a Multidimensional and Dynamic Approach. London: University of Cambridge.

[46] Tarafdar, M., \& Qrunfleh, S. (2013). Lean and agile supply chain strategies and supply chain responsiveness: the role of strategic. Supply Chain Management: An International Journal, Vol. 18 Iss 6 pp. 571 - 582.

[47] Ullah, I. (2012). Role of buyer-supplier relationship and trust in organizational performance. Delhi Business Review, 13(2), 73-82.

[48] Waithaka, P. \&Waiganjo, E. (2015). Role of buyer-supplier relationship on supply chain performance in Kenya ${ }^{\text {ee }}$ s state corporations: A case study of Kenya Tea Development Agency. International Journal of Academic Research in Businessand Social Sciences, 5(4), 136-151.

[49] Wellenbrock, M. (2013). Theoretical basis of supply management: the netwerk theory in supply management (Bachelor's thesis, University of Twente).

[50] Wiengarten, F., Humphreys, P., Cao, G., Fynes, B., \& McKittrick, A. (2010). Collaborative supply chain practices and performance: exploring the key role of information quality. Supply Chain Management: An International Journal.

[51] Yamane, Taro (1972). "Statistics: An introductory analysis." New York: Harper \& Row.
[52] Yan, T., \& Dooley, K. (2014). Buyer-supplier collaboration quality in new product development projects. Journal of Supply Chain Management, 50(2), 59-83.

[53] Zhao, Z., Anand, J., \& Mitchell, W. (2005). A dual networks perspective on inter-organizational transfer of R\&D capabilities: international joint ventures in the Chinese automotive industry. Journal of management studies, 42(1), 127-160.

\section{AUTHORS}

First Author - Bartoo Dorothy Chebichii. (Phd student in Supply Chain Management, Jomo Kenyatta university of Agriculture and technology, Kenya, bartoo.dorothy@yahoo.com Second Author - Professor Gregory Simiyu Namusonge, School of Business,Jomo Kenyatta university of Agriculture and Technology,Kenya email gsnamusonge @jkuat.ac.ke.

Third Author - Dr Elizabeth Nambuswa Makokha, School of Business, Jomo Kenyatta University of Agriculture and Technology ,Kenya.email enambuswa@gmail.com 